\title{
Wstępne wyniki badań petrologicznych i palinologicznych klastów węgla w zlepieńcach formacji menilitowej jednostki śląskiej
}

\author{
Patrycja Wójcik-Tabol ${ }^{1}$, Anna Górecka-Nowak², Grzegorz J. Nowak ${ }^{3}$
}

Preliminary petrological and palinological characteristics of coal clasts from the Menilite Formation of the Silesian Unit. Prz. Geol., 67: 200-203; doi: 10.7306/2019.21

A b s t r a c t. Coal-bearing conglomerates occur in the Menilite Formation of the Silesian Unit, outcropped in the village of Kobielnik. Coal particles are angular and differ in size $(2 \mathrm{~mm}-6 \mathrm{~cm})$. The examined coal shows rather predominance of vitrinite (collotelinite, collodetrinite, vitrodetrinite). However, the presence of inertinite (fusinite, semifusinite and inertodetrinite with rather accessory funginite and secretinite) is also significant. However, liptinite (sporinite, cutinite and resinite) also indicates its presence in the maceral composition. The results of both coal petrographic and palynologcal analyses were conducted with the intention of applying them to reconstruct environments of coal formation. Palynological studies revealed palynofacies consisting mainly of black palynoclasts of rectangle or oval shape. Miospores are abundant and various in colour - from yellow to dark brown. The miospore assemblage is dominated by Lycospora and several other Carboniferous genera occur there. The presence of Radiizonates aligerens (Knox) Staplin, Jansonius, the guide species to the lower part of the Westphalian A (Langsettian) indicate that at least part of the coal pieces come from this part of the Pennsylvanian. The age position of the whole miospore assemblage should be determined as the Late Bashkirian-Moscovian (Westphalian). Additionaly, some older miospores, usually dark in colour, were found in this assemblage and they are considered as reworked.

Keywords: coal-bearing conglomerate, vitrinite, liptinite, inertinite, palynofacies, miospores

Jednostka śląska Karpat zewnętrznych (ryc. 1) jest zbudowana z sukcesji skał osadowych wieku późna jura-miocen, reprezentujących w przewadze facje turbidytowe (Książkiewicz, 1972). Obecność detrytycznego węgla w Karpatach zewnętrznych była wielokrotnie wzmiankowana w literaturze (np. Bukowy, 1957; Kotlarczyk, 1979; Bąk i in., 2015). Egzotyki węgla kamiennego wykazują zróżnicowane cechy petrograficzne oraz mikrofacjalne (Turnau, 1970; Wagner, 1996; Bąk i in., 2015). W warstwach menilitowych w strefie lanckorońsko-żegocińskiej, będącej południową częścią płaszczowiny śląskiej, występują zlepieńce z egzotykami węgla (Burtan, 1978), inter-

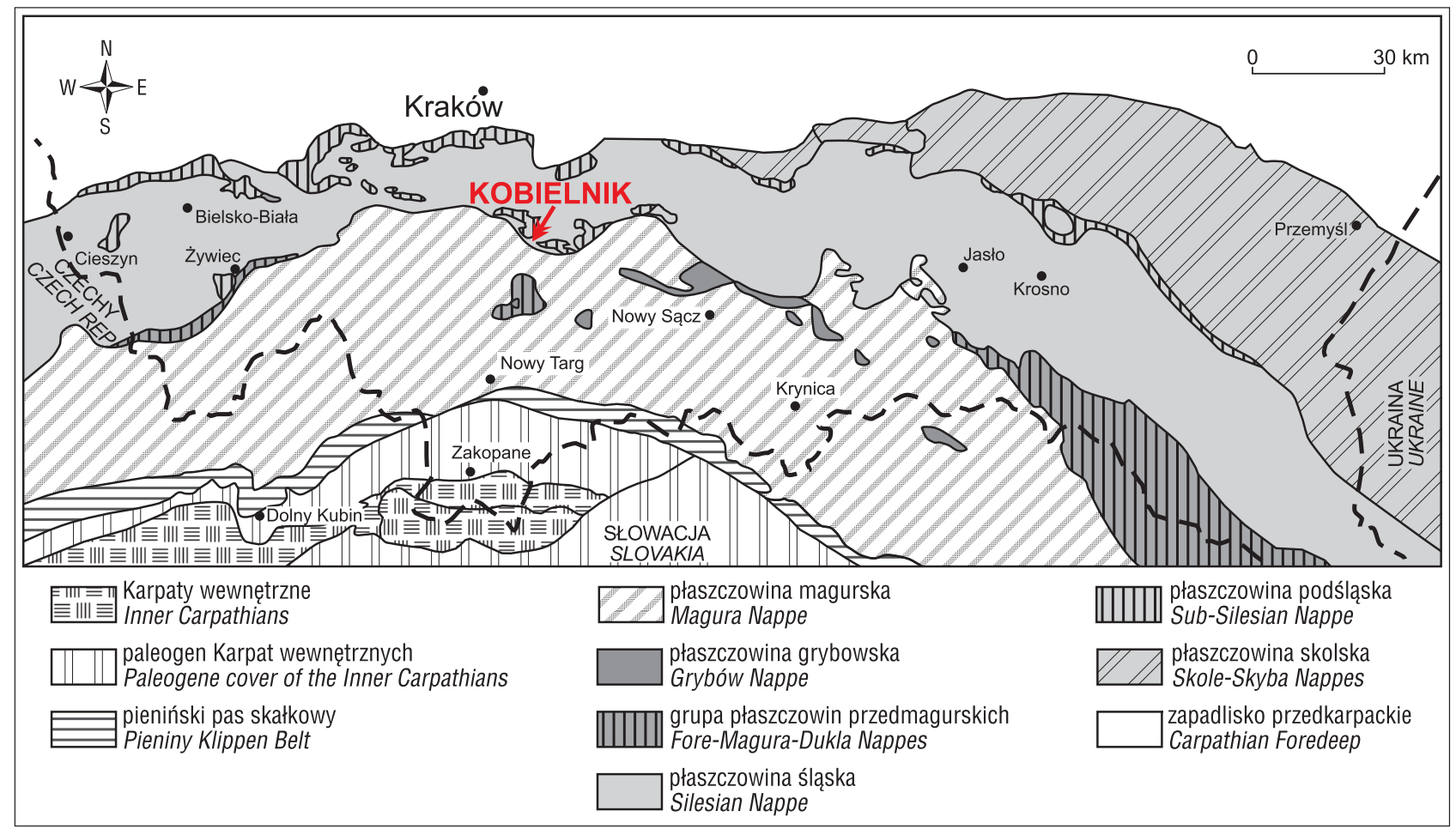

Ryc. 1. Położenie badanego profilu na mapie geologicznej polskich Karpat (wg Książkiewicza, 1972, zmodyfikowane)

Fig. 1. Location of the studied section on the geological map of the Polish Carpathians (after Książkiewicz, 1972, modified)

\footnotetext{
${ }^{1}$ Instytut Nauk Geologicznych, Uniwersytet Jagielloński, Gronostajowa 3a, 30-387 Kraków; p.wojcik-tabol@uj.edu.pl

${ }^{2}$ Instytut Nauk Geologicznych, Uniwersytet Wrocławski, Pl. Maksa Borna 9, 50-204 Wrocław; anna.gorecka-nowak@uwr.edu.pl

3 Państwowy Instytut Geologiczny - Państwowy Instytut Badawczy, Oddział Dolnośląski we Wrocławiu, al. Jaworowa 19, 53-122 Wrocław; gnow@pgi.gov.pl
} 
pretowane jako olistostromy formowane w strefie aktywnych tektonicznie brzegów basenu, w tym usytuowanego na południu grzbietu śląskiego (Polak, 2000). Źródłem egzotyków węgla karbońskiego miało być zagłębie ,prekarpackie", rozwinięte wzdłuż południowej krawędzi platformy europejskiej, niszczone w południowych obszarach m.in. na wypiętrzeniu grzbietu śląskiego (Turnau, 1970; Kotlarczyk, 1979). Jednak węgiel o cechach węgla kamiennego, występujący w formie warstw i soczew w serii turbidytowej bywa także opisywany jako autochtoniczny, równowiekowy osadom, w których występuje (Kotlarczyk, 1979; Wagner, 1996).

Praca przedstawia wstępne wyniki badań petrologicznych i palinologicznych klastów węgla, które obficie występują w zlepieńcach formacji menilitowej w strefie lanckorońsko-żegocińskiej na SW od Wiśniowej. Zlepieńce z klastami węgla przeławicają szare, wapniste mułowce formacji menilitowej, odsłonięte w ścianie nieczynnego kamieniołomu we wsi Kobielnik (ryc. 2).

Opróbowano pięć ławic zlepieńców. Badania mikroskopowe prowadzono w świetle przechodzącym (petrografia zlepieńców i badania palinologiczne) oraz odbitym i ultrafioletowym (petrografia węgla). Badania palinologiczne klastów węglowych wykonano w celu określenia palinofacji oraz wieku badanego materiału węglowego na podstawie rozpoznania zespołu miospor. Badania petrograficzne klastów węglowych pozwoliły zidentyfikować macerały węgla i ustalić środowisko akumulacji węglotwórczej materii organicznej. Wyniki w zestawieniu z cechami sedymentologicznymi i petrologicznymi zlepieńców będą stanowić punkt wyjścia dla pogłębionej analizy proweniencji materiału detrytycznego.

\section{WYNIKI BADAN}

Ławice zlepieńców mają miąższość od 10 do $30 \mathrm{~cm}$ (ryc. 2A). Spągowe powierzchnie ławic są ostre, zaś stropowe często mniej wyraźne z powodu gradacji uziarnienia. Materiał klastyczny o zróżnicowanej wielkości i stopniu

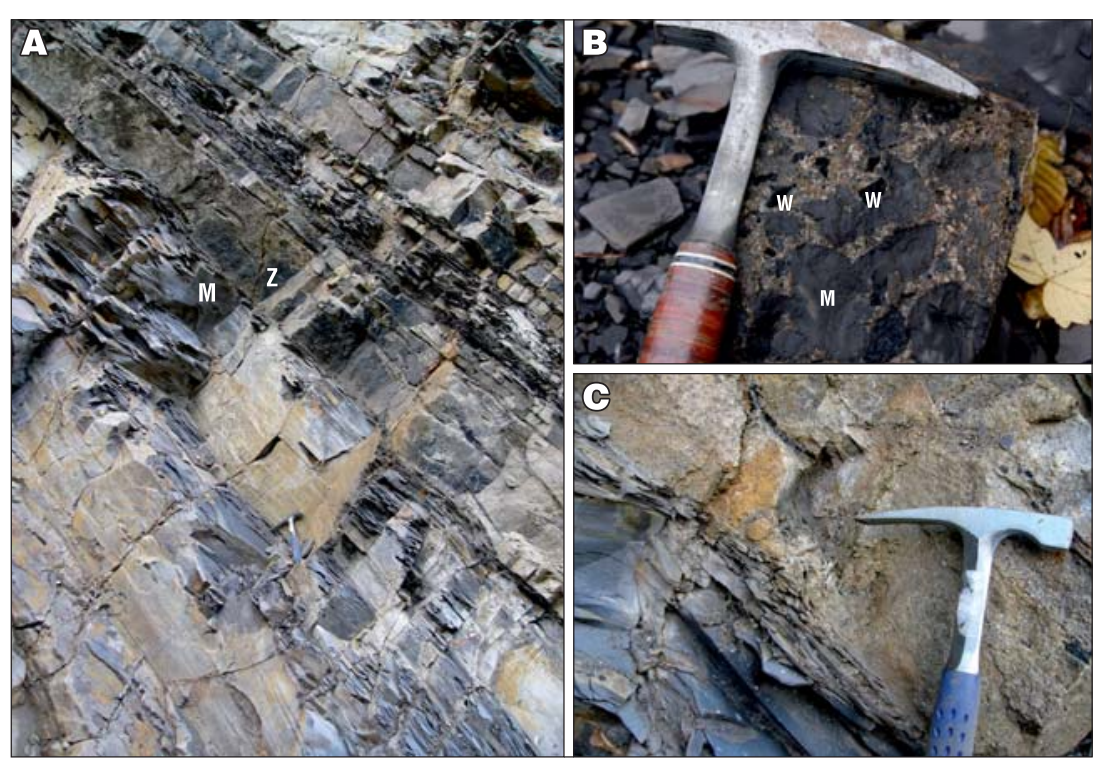

Ryc. 2. Zlepieńce z klastami węgla. A - odsłonięcie przeławiceń szarych mułowców (M) i zlepieńców (Z); B, C - klasty węgla w ławicy zlepieńca (W - węgiel, M - mułowiec). Ryc. 2A, C fot. P. Wójcik-Tabol, ryc. 2B fot. A. Kostuch

Fig. 2. Conglomerates witth coal lithoclasts. A - exposure of alternating conglomerate and mudstone beds; $\mathbf{B}, \mathbf{C}$ - coals lithoclasts occurring in the conglomerate bed (W - coal, $\mathrm{M}$ - mudstone). Figs. 2A, C photo by P. Wójcik-Tabol, Fig. 2B photo by A. Kostuch obtoczenia jest rozmieszczony chaotycznie (ryc. 2B, C). Okruchy węgla są liczne, o wymiarach od kilku mm do $6 \mathrm{~cm}$, przeważnie ostrokrawędziste, rzadziej półobtoczone. Pozostałe składniki szkieletu ziarnowego to ziarna kwarcu i glaukonitu, litoklasty skał węglanowych, krystalicznych oraz okruchowych. Spoiwo o charakterze matriks jest wapniste.

\section{Badania mikroskopowe}

Składnikami dominującymi w obrazie mikroskopowym (ryc. 3A, B) sa ziarna kwarcu i litoklasty skał metamorficznych (kwarcytów i gnejsów) oraz osadowych (wapieni, rogowców, mułowców), a także bioklasty, w tym fragmenty szkieletów i łusek ryb. Klasty węgla są ostrokrawędziste i spękane. Widoczne jest spoiwo typu bazalno-porowego oraz cement węglanowy. Skały sklasyfikowano jako zlepieńce polimiktyczne.

\section{Petrografia węgla}

Węgiel tworzący klasty jest węglem kamiennym. Występują tu macerały reprezentujące trzy grupy - witrynitu, liptynitu $\mathrm{i}$ inertynitu. Jest to spowodowane zarówno warunkami środowiskowymi, w jakich węgiel się tworzył, jak i jego stosunkowo niskim stopniem uwęglenia, reprezentującym niskie stadium węgla kamiennego. $Z$ tej drugiej zależności wynika obecność liptynitu w badanym węglu. Nie uległ on przeobrażeniu w witrynit, cechy typowej dla wyższych stopni uwęglenia.

Badania mikroskopowe (ryc. 3C-F) wskazują na relatywną dominację macerałów grupy witrynitu. Kolodetrynit i kolotelinit są tu najpowszechniejszymi macerałami tej grupy (ryc. 3D, E). Kolotenit ma jasnoszara, jaśniejszą niż kolodetrynit barwę i homogeniczny charakter. Tworzy w klastach drobne pasemka bądź soczewki o różnej grubości. Niektóre z nich wykazują spękania i szczeliny, które czasami wypełnia komponenta mineralna. $\mathrm{Z}$ kolei kolodetrynit ma zdecydowanie niejednorodny charakter. Przybiera on ciemniejszą barwę niż kolotelinit. Macerał ten występuje nie tylko $\mathrm{w}$ formie regularnych pasemek, ale także stanowi tło dla innych macerałów. Oprócz wymienionych kolotelinitu i kolodetrynitu w składzie klastów zaobserwowano też witrodetrynit. Tworzy on drobne ostokrawędziste bądź zaokraglone formy, które są chaotycznie rozproszone wśród innych macerałów.

Najpowszechniej występującym w badanych klastach węglowych macerałem grupy liptynitu jest sporynit (ryc. 3D-F). Ten zbudowany z zewnętrznych błon miospor macerał w obrazie mikroskopowym przybiera kształty soczewkowate, wrzecionowate bądź krótkich pofalowanych wstęg. Badane klasty węglowe wykazują obecność zarówno sporynitu zbudowanego z megaspor (megasporynit), jak również znacznie mniejszych mikrospor (mikrosporynit). Mikrosporynit jest najczęściej reprezentowany przez tenuisporynit, a sporadycznie pojawia się także krassisporynit. Naskórek megasporynitu zwykle objawia ziarnistą budowę wew- 


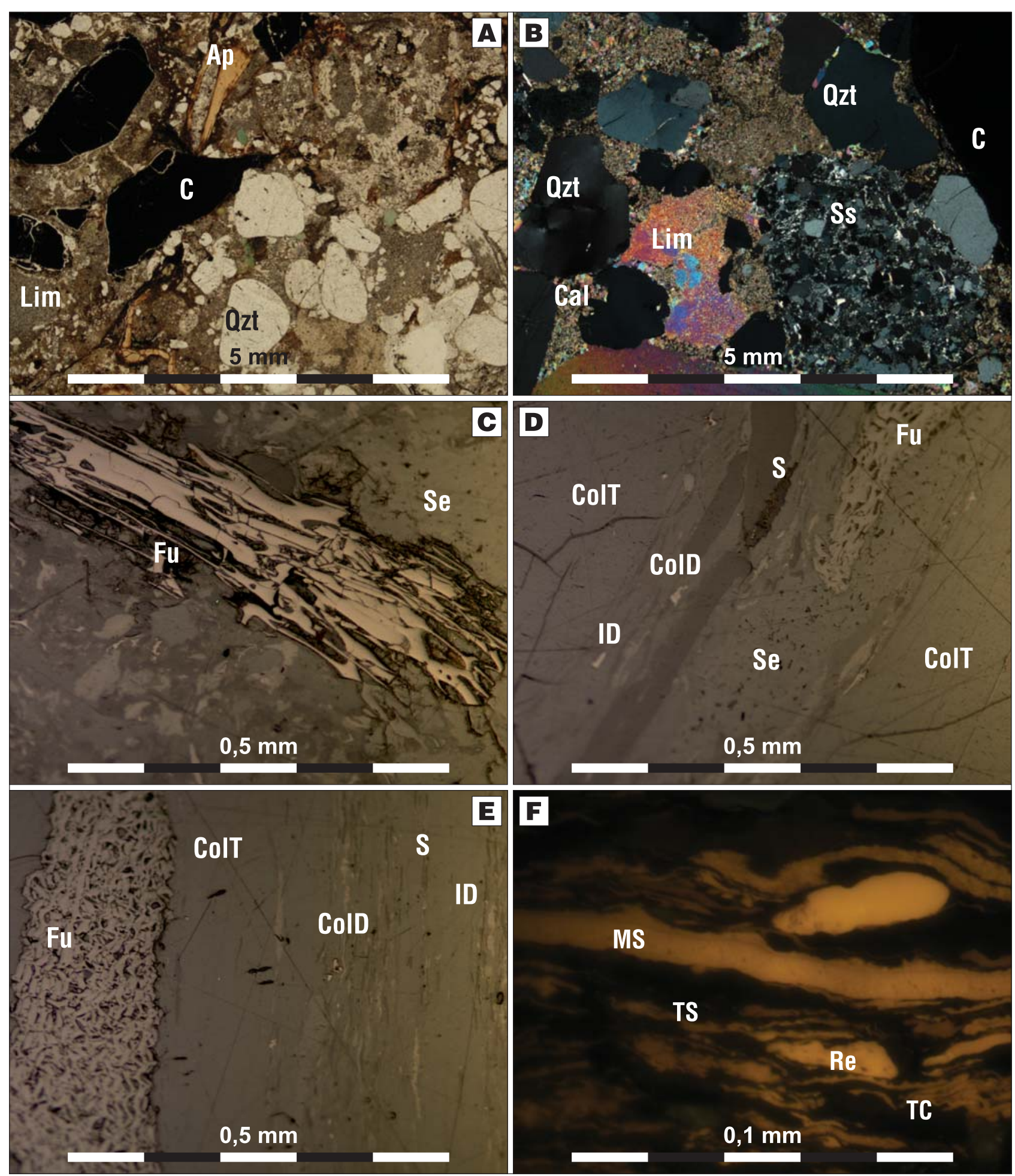

Ryc. 3. Mikrofotografie (A, B - światło przechodzące, $\mathbf{C}-\mathbf{E}$ - światło odbite, $\mathbf{F}$ - światło UV; A, C-F - jeden nikol, $\mathbf{B}$ - skrzyżowane nikole). A, B - zlepieniec: ziarna kwarcu (Qzt), litoklasty: wapieni (Lim), piaskowców (Ss), okruchy węgla (C), fragmenty szkieletu ryby (Ap) spojone cementem kalcytowym (Cal); C - fuzynit (Fu) o zróżnicowanym pokroju ścian komórkowych oraz semifuzynit (Se) o zamkniętych światłach komórek; D - budowa pasemkowa węgla: pasemko kolotelinitu (ColT) tworzące witryt; pasemko klarytu złożone z kolodetrynitu (ColD), sporynitu (S) z dodatkiem inertodetrynitu (ID); pasemko inertytu utworzone z fuzynitu (Fu) i semifuzynitu (Se); E - fuzynit (Fu) o strukturze łukowej graniczący z kolotelinitem (ColT), który ku prawej przechodzi w kolodetrynit (ColD), któremu towarzyszy sporynit (S) i inertodetrynit (ID); F - macerały grupy liptynitu reprezentowane przez sporynit (megasporynit MS, mikrosporynit - tenuisporynit TS), tenuikutynit (TC) i rezynit $(\mathrm{Re})$

Fig. 3. Microphotographs (A, B - transmitted light, $\mathbf{C}-\mathbf{E}$ - reflected light, $\mathbf{F}$ - fluorescence mode; $\mathbf{A}, \mathbf{C}-\mathbf{F}$ - one nicol, $\mathbf{B}$ - crossed nicols). A, B - conglomerate: quartz grains (Qzt), lithoclasts: limestones (Lim), sandstones ( $\mathrm{Ss})$, coals (C) and fish remains (Ap) cemented by calcite (Cal); C - fusinite (Fu) showing different microtexture of cell walls and semifusinite (Se) showing closed cells; D - banded microtexture of coal observed from left to right: a band of vitrinite (collotelinite - ColT) forming vitrite; a band of clarite formed of collodetrinite (ColD) and sporinite (S) plus inertodetrinite (ID); a band of inertite composed of both fusinite (Fu) and semifusinite (Se); $\mathbf{E}$ - fusinite (Fu) of bogen structure bordering on collotelinite (ColT), which passes into collodetrinite (ColD) with associated sporinite (S) and inertodetrinite (ID); F - macerals of liptinite group represented by sporinite (megasporinite MS, microsporinite - tenuisporinite $\mathrm{TS})$, tenuicutinite $(\mathrm{TC})$ and resinite $(\mathrm{Re})$ 
nętrzną, natomiast obserwowany tu tenuisporynit ma bardziej homogeniczny charakter. W świetle białym sporynit wykazuje barwę ciemnoszarą w różnych odcieniach (ryc. 3D, E). Innym macerałem grupy liptynitu obserwowanym w badanych klastach węglowych jest kutynit. Macerał ten występuje jako długie, proste lub pofalowane wstążki, nierzadko jednostronnie postrzępione (ryc. 3F), która to cecha ułatwia jego mikroskopowe odróżnienie od sporynitu. Oznaczono przede wszystkim tenuikutynit, tj. cienkonaskórkową formę kutynitu. W świetle białym kutynit jest ciemnoszary. Odnotowano także obecność rezynitu (ryc. 3F). Występuje on tu jako owalne formy lub tworzy różnokształtne agregaty w obrębie bezstrukturalnego witrynitu. W świetle białym wykazuje szarą barwę - pośrednią pomiędzy barwami witrynitu a sporynitu czy kutynitu. Macerały liptynitu obecne w badanym węglu jako jedyne wykazują zjawisko barwnej fluorescencji, objawiając podczas naświetlania światłem UV kolorystkę od jasnożółtej po ciemnożółtą/pomarańczowożołta.

W badanych klastach zaobserwowano powszechność występowania macerałów grupy inertynitu. Inertynit w badanym węglu to głównie fuzynit i semifuzynit (ryc. 3C-E). Pierwszy z nich cechuje się wysoką refleksyjnością oraz jasnoszarą barwą w świetle odbitym. Występują tu formy fuzynitu pusto- i pełnokomórkowe, grubo- i cienkościenne. Obserwowano także formy o zapłyniętych przestrzeniach komórkowych. Obecność fuzynitu o strukturze łukowej wskazuje na mechaniczną dezintegrację materiału. Semifuzynit pod względem morfologii upodabnia się do fuzynitu, lecz znacznie częściej są obserwowane jego odmiany grubościenne oraz zamkniętych światłach komórek, co może wskazywać na degradację materiału (wcześniejsza jego żelifikacja lub dehydratacja). Semifuzynit ma szarą barwę, pośrednią pomiędzy barwami fuzynitu i witrynitu. Ponadto w badanym węglu powszechnie występuje inertodetrynit. Stwierdzono także funginit i makrynit. Oba macerały są jasnoszarej barwy i wykazują dużą refleksyjność.

W badanym węglu zaobserwowano wysoką degradację materiału, która objawia się powszechnym występowaniem detrytycznych form różnych macerałów, przede wszystkim z grupy inertynitu (najbardziej kruchych) i w mniejszym stopniu także witrynitu.

\section{Badania palinologiczne}

Palinofacja jest zdominowana przez czarne palinoklasty, wśród których palinoklasty o prostokątnym oraz owalnym zarysie występują w zbliżonej liczebności. Brązowe palinoklasty występują podrzędnie i są reprezentowane przez fragmenty drewna o prostokątnym zarysie oraz różne inne, nieidentyfikowalne fragmenty tkanki roślinnej.

Miospory są dość liczne i dobrze zachowane. Wykazują barwę od żółtej do ciemnobrązowej. Obserwacje koloru prowadzone na okazach rodzaju Lycospora również wskazują na zróżnicowowanie - od żółtego do pomarańczowo-brązowego.

Oznaczony zespół miospor jest zdominowany przez okazy z rodzaju Lycospora, będące sporami karbońskich lepidodendridów, stanowiących jedną z najważniejszych grup roślinności węglotwórczej. Rodzaj Lycospora pojawił się na początku wizenu, a jego zasięg stratygraficzny sięga permu. W analizowanej próbce jest reprezentowany przez dwa gatunki - L. pusilla (Ibrahim) Sommers o zasięgu analogicznym jak cały rodzaj i L. orbicula (Potonie, Kremp) Smith, Butterworth, który jest ograniczony wiekowo do westfalu (późnego baszkiru i moskowu). Stwierdzono występowanie przedstawicieli charakterystycznych dla karbonu rodzajów: Calamospora, Camptotriletes, Cyclogranisporites, Densosporites, Granulatisporites, Lophotriletes, Punctatisporites. Oznaczono też taksony typowe dla pensylwanu: Apiculatisporis abditus (Loose) Potonie, Kremp, Crassispora kosankei (Potonie, Kremp) Smith, Butterworth, Radiizonates striatus (Knox) Staplin, Jansonius, Savitrisporites nux (Butterworth, Williams) Smith, Butterworth oraz Verrucosisporites racemus (Peppers) Smith. Na szczególną uwagę zasługuje obecność Radiizonates aligerens (Knox) Staplin, Jansonius, gatunku o bardzo krótkim zasięgu stratygraficznym - tylko wczesny westfal A (wczesny langset). Ponieważ analizowana próbka obejmuje kilka wypreparowanych okruchów węgla, należy przyjąć, że zespół miospor wskazuje na ich westfalski wiek. Z pewnością przynajmniej część okruchów pochodzi $\mathrm{z}$ dolnego westfalu A. W zespole tym znaleziono również pojedyncze okazy starszych taksonów, jak wizeński gatunek Monilospora mutabilis (Staplin) Clayton czy wizeńsko-namurski gatunek Kraeuselisporites echinatus Owens, Mishell \& Marshall. Okazy te wyróżniają się ciemną barwą egzyny, co dodatkowo wskazuje, że są to miospory redeponowane.

\section{WNIOSKI}

Zlepieńce formacji menilitowej w strefie lanckorońsko-żegocińskiej na SW od Wiśniowej są wapnistym zlepieńcami polimiktycznymi, w składzie których klasty węgla towarzyszą ziarnom kwarcu oraz litoklastom skał metamorficznych i osadowych. Klasty węgla są stosunkowo duże i ostrokrawędziste, co dowodzi, że zostały przytransportowane $\mathrm{z}$ nieodległego źródła - erodowanego karbońskiego węgla kamiennego.

Zespół miospor jest zdominowany przez spory karbońskich, węglotwórczych lepidodendridów. Wiek węgla to westfal, a w przypadku przynajmniej części badanych okruchów można zakładać dolny westfal A. Okazy starszych taksonów, będących redeponowanymi miosporami są pojedyncze.

Rozpoznana palinofacja czarnych palinoklastów koreluje się z cechami petrograficznymi węgla i dominacją witrynitu oraz inertynitu nad liptynitem. Powszechność detrytycznych form macerałów świadczy o ich mechanicznej rozdrobnieniu. Obecność liptynitu dowodzi stosunkowo niskiego stopnia uwęglenia węgla.

\section{LITERATURA}

BAKK K., WOLSKA A., ZIELIŃSKA M., BĄK M. 2015- Coal-bearing submarine slump sediments from Oligocene-Miocene transition of the Eastern Carpathians (Bieszczady Mountains, SE Poland). Geol. Quart., 59 (1): 300-315.

BUKOWY S. 1957 - Węgiel kamienny w Karpatach brzeżnych. Prz. Geol., 5: 577-578.

BURTAN J. 1978 - Objaśnienia do Szczegółowej mapy geologicznej Polski 1 : 50 000, ark. Mszana Dolna. Wyd. Geol., Warszawa.

KOTLARCZYK J. 1979 - Węgiel we fliszu karpackim - kilka spostrzeżeń sedymentologicznych. Rocz. Państw. Inst. Geol., 18: 37-150.

KSIĄŻKIEWICZ M. 1972 - Karpaty. [W:] Budowa geologiczna Polski, 4. Tektonika, 3. Wyd. Geol., Warszawa.

POLAK A. 2000 - Poziom gruboziarnistych zlepieńców w okolicy Skrzydlnej (Beskid Wyspowy). Prz. Geol., 48: 644-650.

TURNAU E. 1970 - Mikroflora i paleogeografia karbonu produktywnego w Polskiej części Karpat. Biul. Inst. Geol., 235: 163-244.

WAGNER M. 1996 - Petrologic studies of terrestrial organic matter in Carpathians flysch sediments southern Poland. Inter. J. Coal Geol., 29: 259-272. 